\title{
Other Duties as Assigned: The Hidden Work of Reading and Writing Assessments in Two Primary Classrooms
}

\author{
HOLLY CAROL PARKINSON \\ The University of Western Ontario \\ ROZ STOOKE \\ The University of Western Ontario
}

\begin{abstract}
This article presents findings from a qualitative investigation into the literacy work of two Ontario primary teachers. Informed by the writing of Dorothy E. Smith, we construe the literacy curriculum as a social accomplishment, the product of many people's work. Through a critical examination of field notes and teachers' accounts of their work, we explicate ways in which required reading and writing assessments were mediating a hidden curriculum. Specifically we discuss a paradoxical finding that both teachers organized their literacy curriculum in ways that facilitated the collection of assessment data, yet neither teacher explicitly employed assessment data when making pedagogical decisions and neither teacher mentioned assessment work when describing her school's literacy curriculum.
\end{abstract}

\section{Introduction}

This article discusses findings from a qualitative study of teachers' work in two Ontario primary classrooms. Through a critical examination of observational field notes and teachers' accounts of their work, we show how required reading and writing assessments were mediating the literacy curricula in both classrooms. It is salient to the discussion that neither teacher talked of the required reading and writing assessments as curriculum informants, but only as cumbersome tasks to be carried out in addition to the real work of teaching. Hence the title of our article is Other Duties as Assigned. And yet, in spite of the teachers' assertions that the required reading and writing assessments were unwanted and unwarranted, the data reveal that these other duties were powerful organizers of the teachers' curriculum work. We therefore concur with Apple (1979; 2004) that practices designed to assess the outcomes of a curriculum will mediate the curriculum albeit in unplanned and unwanted ways. Apple called the outcome of these meditational processes "hidden curriculum" by which he meant "the tacit teaching to students of norms, values, and dispositions that goes on simply by their living and coping with the institutional expectations and routines of schools day in and day out for a number of years" (p. 168).

The study on which we base our discussion was not originally designed to focus on assessment work. The overarching question asked in the study was: What work do teachers carry out as they operationalize the expectations of The Ontario Curriculum, Grades 1-8: Language (Ontario Ministry of Education, 2006a)? Indeed, the finding that both teachers were spending such large quantities of time and energy on assessment work 
was an unanticipated discovery. Both authors were interested in learning what teachers actually did as they juggled the complex requirements of the language curriculum with other curriculum requirements and especially with the numerous and various distractions routinely experienced by teachers of young children. As former teachers, we both recalled carrying out tasks such as helping children dress for outdoor play, supervising washroom trips, teaching children to place the yellow paint brush back in the yellow paint pot, and so on. Parkinson wondered if the need to carry out such work would differ from school to school as it had in an earlier Canadian study of teachers' work conducted by Anne Manicom (1995).

In the earlier study, Anne Manicom examined teachers' work in primary classrooms. She observed that all the participating primary teachers carried out work designed to teach self care and the social skills needed for school success, but she also pointed out that such work was unevenly distributed. That is, teachers whose schools were located in poor and working class neighbourhoods were spending more time teaching self care and social skills and less time on the academic curriculum than teachers whose schools were located in affluent neighbourhoods. Manicom argued that the uneven distribution of the work was contributing to the production and maintenance of social inequities since the children who stood to benefit most from a rich academic curriculum at school were spending less time on academic learning than children from affluent neighbourhoods where many parents routinely engaged in complementary educational work (Griffith \& Smith, 2005). Cognizant that Manicom's study predated two decades of school reforms, we expected to learn about new kinds of work and new patterns of work organization in primary classrooms. We were surprised, nevertheless, at the extent to which assessment work dominated the data. Parkinson observed that neither teacher appeared to be spending much time on routines such as keeping paintbrushes clean or tidying toy shelves. Instead the teachers appeared to be occupied and preoccupied with a seemingly relentless stream of tasks associated with reading and writing assessments. Indeed, the necessity to plan, conduct, score, and report the results of reading and writing assessments was creating tensions for the teachers. We came to view assessment work as the antagonist in a "powerful story of school" (Clandinin, Murphy, Huber, \& Orr, 2010, p. $82)$.

Our analysis is also informed by Griffith and André-Bechely's (2008) discussion of test preparation work carried out by parents and elementary grade children in Los Angeles and Toronto. Like Griffith and André-Bechely, we work from the premise that teachers' work is carried out at an "intersection between . . globalizing discourses, educational change, and . . . local experiences with schooling" (p. 42). As did Griffith and André-Bechely, we draw on the theoretical writing of the Canadian feminist sociologist, Dorothy E. Smith $(1987,2005$, 2006), in particular her broad definition of work and her strategies for exploring the coordination of routine work processes in institutional settings. Before presenting the analysis, we, therefore, provide a brief overview of literature that examines the role of literacy assessment in teachers' professional lives.

\section{Literacy Assessments and Teachers' Work}

Education's recent preoccupation with assessment has been associated with and 
sometimes attributed to neoliberal, globalized economic policies (Ballet \& Kelchtermans, 2009; Carlgren \& Klette, 2008; Comber \& Nixon, 2009; Griffith \& André-Bechely, 2008; Hargreaves, 1994; Robertson, 2000; Smyth, Dow, Hattam, Reid, \& Shacklock, 2000; Stevenson, Carter \& Passy, 2007; Webb, Vulliamy, Sarja, Hamelainen, \& Poikonen, 2004) In the wake of globalization, dramatic economic restructuring has created intense pressure on national education systems to prepare students to participate in the new economy (DeVault, 2008, p. 3) and to compete with graduates from other countries. In Canada, the primary responsibility for K-12 education lies with the provinces and territories. Consequently provincial achievement scores are also compared. The demand for comparable measures has created a demand for standardized assessments and it has also created a great deal of stress in the lives of teachers, students and their families. Indeed, the practice of publishing school assessment scores in the popular press ensures that the pressure to compete internationally is being increasingly experienced at a local level.

Embedded in the globalized policies are "conceptual currencies of effectiveness and skill" that represent teachers' responsibilities in increasingly economic terms and produce "[n] ew forms of performance management" (DeVault, 2008, p. 40). In teachers' professional lives, the new forms of performance management often take the form of standardized achievement assessments. Black (2004, p. 28) describes teachers as "anxious and apprehensive, especially about meeting the mounting needs of troubled students, doing justice to an all-consuming curriculum, and getting kids ready for a relentless series of tests". More recently, Australian researchers Comber and Nixon (2009) report being "struck" by secondary teachers' unwillingness to talk about pedagogy. In interviews with the researchers the teachers preferred to dwell on a plethora of "seemingly pointless bureaucratic demands" (p. 334).

Although it has been argued that they produce "fragile evidence" (Murphy, 1996), literacy assessments have assumed a central place in educational reforms. Numerous studies implicate high-stakes reading and writing assessments in teachers' work intensification (e.g., Hoffman \& Goodman, 2009; Invernizzi, Lundrum, Howell, \& Harley, 2008; Purcell-Gates, Degener \& Jacobson, 2004; Teale, Hoffman, Paciga, Lisy, \& Berkel, 2009; Valli \& Buese, 2007). The comments below were made by Kaia Tollefson (2008), an American teacher researcher who took time out from graduate studies to experience first-hand the effects of the new regime of accountability on teachers' professional lives. Tollefson recalls that "[w]ith nearly two decades in education behind me, it was very difficult throughout that year to claim the right to define myself as a teacher and to hold onto my own professional values" (p. 17). She was angry to learn that some novice teachers did not have opportunities to learn from experience and reflect on their practice.

Without the invitation to spend their novice years experimenting in safety, making mistakes and learning from them with the help of experienced mentors, they were urged instead to focus their efforts on becoming efficient data-collectors and to care only about quantifiable results. (p. 18)

Secondary teachers have always been responsible for quantifiable results. However, 
before the 1990s, primary teaching was less affected by standards-based reforms and accountability programs. By the year 2000, however, even researchers in the early childhood field were noticing that "professional commitment to play [was] being eroded" in a "political climate dominated by the language of standards and outcomes" (Lubeck, 2000, p. 3). In the United States, programs such as Early Reading First (United States Department of Education, n.d.) mandated the intentional teaching of literacy skills to children in the early primary grades, but the resulting focus on test scores led some reformers to liken the situation to Dickens' A Tale of Two Cities.

It is the best of times, it is the worst of times . . we are all going direct to heaven for our attention to children's early literacy, we are all going direct the other way because of what we are doing in the name of early literacy. (Teale, 2004, cited in Teale et al.,, 2009, pp. 83-84)

Teale et al. (2009) welcome the intentional teaching of literacy in early primary classrooms, but at the same time they express a deep concern about the preoccupation with reading and writing assessment. In particular, they regret the misuse and non-use of assessment data. While well designed, diagnostic literacy assessments can be rich sources of data for instructional decision-making, many standardized assessments, those assessments that are administered and scored in a standard way, have become a major source of stress and alienation for teachers who tend to view them as bureaucratic tasks to be done "in addition to - and apart from-instruction" (p. 90). And yet, as noted earlier in this section, the consequences of some high-stakes, standardized assessments may be keenly felt by individual students, their families, teachers and even entire schools.

It is understandable that teachers might privilege the requirements of high-stakes assessments over the requirements of the official curriculum. Johnson and Kress (2003) sum up the situation as follows: "Despite years of debate on the nature of literacy and curriculum and ensuing policy directions, it is assessment-its weighting in the political culture and the means of enforcing that culture, which will guide what is taught and how it is taught" (p. 11). It is equally understandable that teachers would require students to demonstrate knowledge and skills in formats that replicate the formats specified by the assessments. Assigning practice tests, creating highly controlled environments for in-class assignments, and privileging paper and pencil activities over other modes of expression are strategies that can help students do better on standardized paper-pencil tests. At the same time, they may mediate a hidden curriculum that alienates students from school tasks and fosters grade-dependence. And for teachers themselves, a relentless requirement to gather assessment data can erode commitment to other practices. Even teachers who personally value creative activities and take an expanded view of literacy may come to believe that time is better spent on efficient, test-oriented reading and writing activities. Consequently, certain kinds of content and certain pedagogical practices are devalued or excluded when the direct relevance to an assessment is not immediately apparent. Teale (2008), for example, writes that when assessments of early literacy focus exclusively on decoding skills, educators should not be surprised to "wake up around middle school to discover that . . . students can't develop interpretations, read critically, write a decent extended response to a piece of literature, and so on" (p. 360). 
Teaching to the test provides a powerful illustration of a social process that Smith calls extralocal coordination and it is to this topic that we now turn.

\section{The Extralocally-Coordinated Literacy Curriculum}

The study on which our analysis is based was informed by the theoretical writing and teaching of Canadian sociologist, Dorothy Smith (1987, 2005, 2006). Smith proposes an "ontology of the social" that conceptualizes social life as an ongoing, coordinated accomplishment produced by people going about routine activities in local settings. Within a setting, individual people coordinate their actions with the actions of other people - as in a dance. Whatever people do that contributes to the production of social life in the setting, for example a classroom, counts as work. Smith proposes that many routine work processes in people's everyday and professional lives hook their actions into a broader web of coordination that extends beyond local sites. She uses the term ruling relations and notes that the ruling relations are comprised of large institutions such as education, health care and the economy. She developed a way of looking at institutions "from where we actually live, into the powers, processes, and relations that organize and determine the everyday context of that seeing" (Smith, 1987, p. 9) and teaches that way of looking to others, not as theory, but as political practice (Smith, 2006).

We were drawn to Smith's ideas because they refocus the research lens "away from questions generated by administrative concerns and toward the puzzles of people's everyday lives" (DeVault, 2011, n.p.). Her proposition that social life is the ongoing coordination of activities is appropriate to a discussion of curriculum work since it represents curriculum as a dynamic process - what people say and do in classroom interactions, not just a set of instructions laid out in an official curriculum document. The related notions of local and extralocal coordination of work enabled us to think of classroom interactions in a broader sociopolitical context, that is, as interactions mediated by work processes carried out elsewhere. When teachers mobilize curriculum expectations, for example, their work is entered into extralocal processes that standardize teachers' work within diverse sites across Ontario.

Smith has written at length on the topic of textually-mediated coordination (e.g., Smith, 2006). She argues that in post-industrial societies such as Canada, people's interactions with the ruling relations are mediated by a plethora of official texts. Identifying the texts that seem to be mediating people's actions and examining how people in a local setting interact with those texts is a strategy for understanding how work is being coordinated locally and extralocally. As Griffith and André-Bechely (2008) put it: "To understand the intersections between globalization" and work in local settings, "research must attend to the social relations of ruling that are coordinated textually" ( $\mathrm{p}$. 46).

The Ontario curriculum is an exemplary regulatory text. However, numerous other texts also provide opportunities for teachers' work to be entered into the ruling relations. We assert, for example, that by carrying out the required assessments, the teachers who participated in the study were also participating in work processes originating elsewhere. As we noted in the previous section, the trend toward increased accountability and assessment is an international one.

Smith $(1987,2005,2006)$ argues that the processes of coordination are not always 
visible to people going about their everyday lives, but people's routine actions and their descriptions of what they are doing in a setting contain clues to understanding how work in a setting is being coordinated with work in other settings. Consider for example, the practice of recording student assessment data on a school's data wall. This action connects the teacher's curriculum work to the work of other teachers at the school, but it also points to the possibility that the data will be entered into other officially sanctioned work processes. For example, scores can be compared within and across grades and assessment data can be aggregated by research officers in school boards and ministries. A board's project to identify what they call "schools in the middle," that is, schools whose scores are at an average level, but could be improved, relies heavily on comparisons of assessment scores across school sites. It is worth noting that the use of the word "data" rather than "grade" or "score" is not trivial, but suggests that teachers are participating in research. The question raised, of course, is to what end and for whose purposes is the research being carried out?

Smith's observations about textual mediation of work apply primarily to the kinds of texts she calls replicable texts $(2006$, p. 66). Texts are "words, images or sounds that are set into a material form of some kind from which they can be read, seen, heard, watched, and so on" (2006, p. 66). A text is replicable if "anyone else anywhere else can read, see, hear, and so on the same words, images, or sounds as any other person engaged with the same text" (p. 66). Replicable texts have a "magical character" because "they are read, seen, heard, watched, and so on in particular local and observable settings while at the same time hooking up an individual's consciousness into relations that are translocal" (p. 66). Smith is particularly interested in the kinds of texts that mediate institutional work, for example, the official curriculum, the student report card, the attendance register and other forms of paperwork. A data wall such as the one described above is also a replicable text because teachers are expected to add data to the wall in a standard way and teachers are instructed in how to read the data recorded by their colleagues. Standardized literacy assessment protocols are just a few of the workplace texts that mediate teachers' work. Our analysis focuses on them because they featured so prominently in the observational field notes and in the teachers' accounts of their work.

\section{Setting, Participants, and Data Collection}

Data for the study were collected in two primary classrooms over a two-week time period. The classrooms were located in different neighbourhoods of the same mid-size Ontario city. Uppercross School (all names have been changed) was located in an affluent, suburban neighbourhood; Longbourne was located in a semi-industrial and less affluent neighbourhood. Two teachers, Jane and Emma, participated in the study. Parkinson, an experienced primary teacher familiar with primary classrooms in Canada and the UK, spent a week as a participant observer in each teacher's classroom.

Jane taught a grade one-two split class at Uppercross, a school situated on a quiet, tree-lined street. Many of the large houses nearby had manicured lawns and were owned by retired people; a few houses were owned by professional families with school-aged children. The school had split grade classes of about twenty students each and a student enrolment of about 230 students from junior kindergarten to grade eight. Some children went home for lunch, but most children brought packed lunches to school. Teachers said 
that lunchtime supervision was not difficult because of the small size of the classes. Each of them was responsible for seven periods of yard duty during each week. Jane had worked as a teacher for almost twenty years. She taught nine grade one and ten grade two students, four of whom she described as having "special needs." As the school's music specialist, she also taught music to grade three and held a weekly, lunch-hour, cross-grade choir practice.

Emma taught 19 grade one students at Longbourne, an elementary school serving a population of about three hundred students from junior kindergarten to grade eight. Longbourne was situated in a semi-industrial, older area of the city. Few trees, but many fast-food restaurants lined the streets nearby. The residential parts of the neighbourhood contained several rent-geared-to-income apartment buildings along with modest, older houses. The school itself was almost sixty years old and located near a busy traffic intersection. There was a factory next door and the industrial pollution in the air was noticeable, but the schoolyard afforded a grass and pavement playground and the school was clean and neatly kept. Outside of the busy office there were bulletin boards that held information notices for parents. The hallways were decorated with students' art work and samples of student writing. In the primary wing each class ate snacks and lunches with one other class to minimize clean-up work and supervision. Longbourne organized the day on a "balanced six-day schedule" with two 45 minute nutrition breaks rather than one lunch hour and two recesses. The children brought their own packed lunches and a few students went home to eat on one of the breaks. Teachers were assigned two duty periods of about twenty minutes each week. Emma described her class as mostly "needy." She had been working as a primary teacher for more than ten years and previously worked as an educational assistant in primary classrooms. She did not coordinate any extra-curricular activities, but several times during the observation week, she used one nutrition break to tutor a hearing-impaired student who had been in her class the previous year.

As noted above, Holly acted as a participant observer for one week in each classroom, arriving at each school when the participating teacher arrived at the school and leaving when the teacher left. To ensure trustworthiness, she aimed to look closely, carefully and relatively unobtrusively at the teachers' work and composed detailed, descriptive, concretely-focused field notes based on the observations and informal conversations with each teacher. When asked, she assisted groups of children with teacher-initiated activities including the administration of the required Developmental Reading Assessment (Beaver \& Carter, 2004). At the end of each day she composed written reflections that elaborated the observational field notes. She also recorded and transcribed a semi-structured interview with each teacher.

\section{Data Analysis}

The data were coded in several ways. First we employed two broad categories: official curriculum work and other duties. This first iteration of coding afforded few new insights. As Table 1 shows, literacy lessons in both classrooms were easily referenced to the Ontario curriculum expectations. Outside of planned lessons, however, the matching of actions with curriculum expectations proved difficult. We concluded that the problem was a methodological one. The curriculum expectations constitute a fine-grained scheme 
for lesson planning, but the list of expectations may be too fine-grained a scheme for examining informal classroom activities. We had anticipated too that the teachers would be carrying out the kinds of extra-curricular work observed by Manicom and were surprised to find so little evidence of teachers showing students how to keep toy shelves tidy, how to "play nicely" at the sand table and so on. Neither classroom contained a water or sand table, or messy materials such as clay and paint. And more important, neither schedule included time for play-based learning. Toys were available in one classroom, but they were to be used only at recess. In fact, Jane commented that she did not want the children to play during the school day as there was too much other work to do and "not enough time."

If the first round of coding afforded few insights, it did raise a useful question. We wondered: If there is no time for play and if the teachers were not preoccupied with the teaching of self-care routines and classroom housekeeping, what kept them so busy and frustrated? We recategorized the data using four components of the instructional cycle: assessment, planning, preparation, implementation. The new categorization revealed that gathering and reporting assessment data was consuming inordinate amounts of the teachers' time. In addition to the actual administration of assessments, teachers planned their schedules and the contents of lessons to make space for the gathering and reporting of assessment data. Paradoxically, except for references to students' levels for selecting reading materials and planning literacy centre activities, there were no references in the field notes or interview transcripts to teachers actually interpreting assessment data for pedagogical decision-making. Emma, for example, said that she knew "where the students were" without doing the required writing assessment.

Table 1

Curriculum Expectations Addressed in Four Literacy Lessons

\begin{tabular}{|c|c|}
\hline $\begin{array}{l}\text { The Ontario curriculum, grades } 1-8 \text { : } \\
\text { language }\end{array}$ & Uppercross \\
\hline $\begin{array}{l}\text { Reading 3.2: Uses graphophonic cues (e.g. } \\
\text { blending and segmenting sounds in words; } \\
\text { visual features of words such as shape and } \\
\text { orientation). } \\
\text { Oral Communication } \mathrm{K} 11 \text { : Demonstrate } \\
\text { awareness that words can rhyme, and are } \\
\text { composed of phonemes that can be } \\
\text { manipulated to create new words. }\end{array}$ & $\begin{array}{l}\text { Each child had paper letters for 'thank' } \\
\text { and were asked to remove 'th' and make } \\
\text { new words such as tank, bank, sank, blank, } \\
\text { drank. During the word blending lesson a } \\
\text { grade one student raised her hand and } \\
\text { suggested putting the letters 'f' and 'r' in } \\
\text { front of 'ank' to make the name 'Frank'. } \\
\text { Ms. Jane said to make the 'f' uppercase } \\
\text { and explained why }\end{array}$ \\
\hline $\begin{array}{l}\text { Writing 2.1: Write short texts using several } \\
\text { simple forms. Writing, 2.6: Identify } \\
\text { elements of their writing that need } \\
\text { improvement. Writing, 3.1: Spell unfamiliar } \\
\text { words using a variety of strategies ... }\end{array}$ & $\begin{array}{l}\text { Students wrote stories about being } \\
\text { thankful. Jane and Parkinson } \\
\text { individually checked the students' spelling } \\
\text { and punctuation in process. }\end{array}$ \\
\hline $\begin{array}{l}\text { Oral Communication 1.9: Begin to identify } \\
\text { some of the presentation strategies used in } \\
\text { oral texts and explain how they influence }\end{array}$ & $\begin{array}{l}\text { Whole class lesson at the carpet } \\
\text { Shared reading and singing using stories, } \\
\text { poems and lyrics from big books }\end{array}$ \\
\hline
\end{tabular}




\begin{tabular}{|c|c|}
\hline $\begin{array}{l}\text { the audience. Speaking to Communicate 2.2: } \\
\text { Demonstrate an understanding of } \\
\text { appropriate speaking behavior... in large } \\
\text { group discussions. Speaking to } \\
\text { Communicate 2.7: Use one or more } \\
\text { appropriate visual aids to support or } \\
\text { enhance oral presentations. } \\
\text { Reading, 2.2: Recognize simple } \\
\text { organizational patterns in texts of different } \\
\text { types and explain... how the patterns help } \\
\text { readers understand the texts. Reading, 2.3: } \\
\text { Identify some text features. }\end{array}$ & $\begin{array}{l}\text { Accompaniment with music from compact } \\
\text { discs } \\
\text { Use of puppets }\end{array}$ \\
\hline $\begin{array}{l}\text { The Kindergarten Program expectations } \\
\text { (Ontario Ministry of Education, 2006b) }\end{array}$ & Longbourne \\
\hline $\begin{array}{l}\text { Reading } K 2: \text { Demonstrate knowledge of } \\
\text { most letters of the alphabet in different } \\
\text { contexts. } \\
\text { Writing } K 24 \text { : Demonstrate awareness that } \\
\text { Writing can convey ideas of messages. } \\
\text { Writing } K 26 \text { : Begin to use classroom } \\
\text { resources to support their writing. }\end{array}$ & $\begin{array}{l}\text { Morning message. Emma wrote on white } \\
\text { board. The message contained } 2-3 \\
\text { sentences with missing letters and words, } \\
\text { incorrect uppercase or lowercase letters, } \\
\text { missing punctuation, simple incorrect } \\
\text { grammar. Daily focus one or more } \\
\text { "mistake" }\end{array}$ \\
\hline
\end{tabular}

The teachers' accounts of their literacy assessment work tended to focus on official texts such as the Developmental Reading Assessment (DRA) and the Ontario Provincial Writing Assessment (Nelson Education, 2008), but Jane also showed Holly several binders of locally-produced rubrics and information about assessments. It was also evident that almost all print-based artifacts produced by the students were viewed as assessment data to inform completion of the report card. We therefore begin the discussion of texts with notes about Ontario's Provincial Report Card.

\section{The Provincial Report Card}

The report card was authorized by the provincial government and was to be completed online in a standardized way. Teachers were expected to use a bank of predetermined comments matched to the curriculum expectations. Fitting the actual activities of children into prescribed categories and using a comment bank created tensions and much work for teachers. Jane said record keeping for her was a daily routine that she organized with a view to completing the next report card. She assigned about 30 minutes each day to small assessment tasks and sometimes planned "big assessments" that took up to 90 minutes. She said, "I know how they are doing, because the children who need a lot of help, obviously will not get a 'B' on their report cards."

Emma particularly resented the lack of flexibility afforded by the Provincial Report Card's online comment bank. She said, "The reporting process should be easier and more personalized." She also said that report cards "encompass all the work the children have done during that term." She therefore marked everything that the students handed in. She had anecdotal notes, DRA records, a binder of running record forms to be 
used when she would "eventually listen to them read," and another binder for writing samples that students completed at the classroom writing centre.

Emma would ask the children to drop everything and read (DEAR) every day for twenty minutes after their first nutrition break and during the DEAR time she invited individual students to her table to review their take home books, to assess their oral reading accuracy and comprehension and to record the assessment information in her record book.

We inferred that the Provincial Report Card was mediating the curriculum in Jane and Emma's classrooms in at least three ways. First, even though report cards would not be completed during Holly's site visits, both Jane and Emma kept the requirements of the report card in view as they organized informal assessment tasks and lessons and aligned their planning work to match its categories. Second, the report card played a role in the scheduling of curriculum content and the fragmenting of the curriculum. Jane said, "We have expectations that we need to cover, so we (teachers) want to make sure that we have covered all of them." Third, the actual completion of the report card consumed a great deal of time. In spite of their forethought and efforts to be prepared, the teachers described report card writing as overwhelming. Both of them commented that having to work evenings and weekends and then to plan and prepare lessons as usual caused over-tiredness, stress, anxiety, sickness, and missed work days. The result was often that lessons were not planned, or organized to their satisfaction.

Emma: Grade one report cards---I would say working on your own time, working in the evening, on the weekends, probably a span of two weeks to get report cards done.

Jane: Oh, the report cards would take a good two weeks. The comments are always the toughest because I need to and want to make sure that I'm talking about the child and making sure I have the comments. I want to be positive yet I want to say what I want to say. So I find the final comments usually take the longest time.

\section{The Developmental Reading Assessment (DRA)}

The DRA consists of a set of passages to be read aloud by the student and a standardized recording protocol for the person conducting the assessment. Passages are organized in order of increasing difficulty. Each student reads one or more DRA passage to the assessor until their oral reading accuracy falls below a designated "frustration" level. Students also respond orally to predetermined questions, retell the contents of passages in their own words and relate the content to personal experiences. Accuracy, fluency and comprehension scores are determined in standardized ways and recorded on the protocol along with notes about the student's strategies and reading behaviours. The reporting of DRA data was required by Jane and Emma's school district, once in the fall and once in the spring. Scores were submitted to the principal who documented and reported the school's scores to the school district.

The difficulty levels assigned to DRA passages and the levels assigned to DRA levelled books are aligned and the increments from level to level allow students to progress through the levels in a seamless way. This allows DRA data to be used both for 
tracking and planning. A problem arises, however, when instructional needs are conceptualized exclusively in terms of numerical levels. As Allington and McGill-Frantzen (2009) point out, such an approach is particularly unhelpful for students who need comprehension support.

DRA assessments created a lot of work for the participating teachers and their students. Why, then, was the DRA described by the teachers as just another duty to get done? One reason could be the DRA's lack of alignment with the official curriculum expectations. Although one teacher did report DRA scores to parents, teachers were told that scores were not to be communicated on the Report Card. We suspect, however, that the teachers' dislike of DRA stemmed primarily from the labour-intensive nature of the assessment process. Each assessment was to be completed individually in a quiet space with no disruptions which meant that the class as a whole needed to be engaged in quiet independent work while the teacher conducted assessments. We heard that some teachers would ask volunteers to conduct the assessments and some administrators would "help out." The DRA therefore got done, but not in a way that afforded many learning opportunities for students or their teachers.

The data contain no comments about the diagnostic potential of the DRA. Emma said her students did not provide sufficient data for her to plan instruction. Jane's students were doing well regardless of the data provided by the DRA. Ironically, doing well provided no respite from assessments. Parkinson conducted DRA assessments in Jane's class and noted that students who were reading well required more time to complete the DRA than students in Emma's class who were reading below the expected standard for the grade.

Field Note (Uppercross): Jane's children were reading at high levels, some grade one students...took about twenty minutes to complete all of the required reading, comprehension, fluency, and questioning sections... In previous years, before the current principal came to Uppercross, Jane and the kindergarten teacher used to join their classes. While one teacher supervised [both classes], the other teacher did the DRA testing. This year, the principal helped out. She removed each child from the class and did the assessment so as not to have the disruption from the other students in the classroom. However, Jane was not told in advance when the principal would be arriving. She could not successfully coordinate her instruction to ensure that each student would miss the least possible amount of instruction and found that she had to spend extra time to help each child catch up work that was missed.

Field Note (Longbourne): Emma spoke of the DRA. She said she did not need anybody's help with them this year as all of the children were at low levels and she was able to do the assessments quickly. A low level test takes about five to ten minutes to complete and Emma was able to complete the assessment tests in a few afternoons while the other children were having free time at centres-building, doing puzzles, drawing, and so on. Emma said that help was offered from the school to either do the tests or give Emma some cover (an extra teacher). Perhaps at the next DRA assessment in the spring...Emma might accept the offer 
of help.

The principals' offers of help with DRA assessments suggest that they too may have viewed the assessments as other duties. Ironically, Jane's inability to predict when her principal would be available to help only exacerbated her anxiety and made her reluctant to commit large blocks of time to lessons that required sustained attention in case the principal chose that time to help. The end result in Jane's classroom was the planning of cognitively undemanding busy work.

\section{The Binder Story}

As former classroom teachers, we are aware that a school year has its own rhythm. The DRA may be scheduled twice a year, but between DRA assessments there should be time for planning rich learning experiences. Holly was therefore surprised to learn from both teachers that more assessment requirements were being imposed just as the DRA assessments were completed. Indeed, in light of the demonstrated reading achievement of Jane's students, the following story is baffling.

Field Note: (Uppercross): On my final day in Jane's classroom I attended a meeting before school with Jane and the principal. The principal introduced a new reading assessment task that had been passed on to her by someone at the Board. The assessment was to be conducted once per month starting the following month in addition to the two administrations of the DRA. Jane was given two large binders containing instructions for administering and interpreting the reading assessments. Each child was to complete tasks focused on oral and silent reading, fluency, and comprehension. Each assessment would take about fifteen to twenty minutes. Jane said to me later the same day that the assessments were just more stuff for her to do and much organizing would be necessary to make the assessments happen. She was hoping the principal would have the time to help her. She did not appear pleased. . . When would she have the time? With 19 students the time required would be at least six hours each month. She needed to plan independent activities for the group and each child would need to be protected from distractions during the assessment.

\section{The Provincial Writing Assessment}

The Ontario Provincial Writing Assessment (Nelson Education, 2008) is aligned with the Ontario writing expectations. Its purpose is to assist teachers in assessing students' work in relation to the Ontario Achievement Chart (Ontario Ministry of Education, 2006a). The manual suggests administering the assessment three times a year, but also states that schools could complete it many times.

Field Note (Longbourne): Emma told me about an Ontario Provincial Writing Assessment she needs to complete during the next week or so. Emma showed the assessment package to me and explained that it was a 'must do' assessment for her students and "just another thing I have to do that's extra." She told me it was a lot of work to complete a pre-test, post-test, and a tracking sheet six times during 
the year, but the principal wants her to complete the assessment every time she starts a new unit.

For the first assessment, the children were to draw a picture of themselves playing at recess and then to write a list of the recess rules. Emma did not expect the children would use invented spelling. She said that her students had difficulties even copying print. She "already knows where they are" which is at the senior kindergarten level. She will have to modify the task itself to make it possible for her students to participate. She thinks she will use a Thanksgiving topic and a guided writing activity that she had previously worked on with the students. She will have to organize some self-sustaining, independent activities for the other children to do while she works with each small group on the assessment task. Emma said she knows that when the assessment tasks are completed in that way they won't be valid as the teacher will have helped the students. Hopefully, towards the middle of the school year, her students will be ready to work on the easier assessment tasks listed in the provincial document, but she thinks by the end of the school year they won't be up to the provincial standards required for grade one.

In addition to the issues already raised in relation to the DRA, the Binder Story and Provincial Writing Assessment story raise questions about the arbitrary imposition of literacy assessments. Certainly the need for the additional assessment data was not transparent to the teachers. Why would students who were already doing well be participating in another set of assessments? However, as baffling as the Binder Story was, Emma's Writing Assessment story elicited greater concern. Why did Emma feel a need to adjust the writing assessment tasks and build a guided writing lesson around an artificial task even though she knew the assessment results would not be valid? We inferred that like the teachers who participated in Comber and Nixon's (2009) study, Jane and Emma were approaching the assessments as bureaucratic requirements that actually got in the way of their curriculum work.

\section{Discussion}

In both classrooms, assessment work was taking up inordinate amounts of time. In this section we consider some implications of this finding. Our discussion takes up the absence of the teachers' comments about assessments in their descriptions of curriculum work beginning from the teachers' descriptions.

In the following quote, Jane describes what she means by balanced literacy, an approach that Uppercross had adopted as a school.

Jane: We have a Balanced Literacy program, so we do shared reading, guided reading, independent reading once they are more independent in their reading. And then we have centre activities or we have USSR [uninterrupted sustained silent reading]. Writing would be different [kinds of writing such as] morning message, interactive writing, shared writing and independent writing. 
Jane then explained that her classroom literacy program reflected and complemented what the whole school was doing. For example, she planned literacy centres according to the "literacy levels" of her students, an approach that was being used throughout the primary grades.

Jane's elaboration of balanced literacy identified the four contexts for reading and writing described in A Guide to Effective Instruction in Reading: Kindergarten - Grade 3 (Ontario Ministry of Education, 2004 ) and A Guide to Effective Instruction in Writing Kindergarten - to Grade 3 (Ontario Ministry of Education, 2005). However, Jane made no mention of assessment, even though the curriculum document and both guides to effective instruction contain information related to assessment practices. It is interesting too that Jane's description construed literacy as reading and writing although Table 1 contains evidence that she employed multimodal strategies in her shared reading lessons.

Emma's school had not adopted balanced literacy, but had opted instead to implement a literacy hour. Emma's description of her curriculum focused exclusively on print literacy and whole group activities, and she too made no mention of assessment unless we consider the references to levelled books. In previous years, Emma had stayed late on a Friday to select the levelled books for the following week and to fill out a staff chart in the levelled book room so that other teachers would know what books were being used.

Emma: Something for language arts would be our literacy hour which is in the morning. Right now we're just working on . . . our September and October printing books. The planning would be getting at the resources from the resource room, getting reading response activities for all of the centres actually. Sometimes we use the word wall as a centre. So, for language arts, it is our guided reading, guided writing, interactive writing. We try to do a little modeled writing and interactive writing when we write our books.

The teachers' descriptions of their curricula led us to wonder how the assessment data were employed in pedagogical decisions. To paraphrase Apple (2004), we wondered how assessment practices were mediating the hidden curriculum? Our discussion employs the related notion of a null curriculum as discussed by Pinar, Reynolds, Slattery, and Taubman (2008). Pinar et al. define the "null or unstudied curriculum" as "those topics not included in the official curriculum" (p. 27). They define the hidden curriculum as the "unwanted outcomes of schooling" (p. 27) and as "the ideological and subliminal message presented within the overt curriculum, as well as a by-product of the null curriculum" (p. 27).

The null curriculum can be described in terms of silences and absences. Pinar et al. (2008) define the "null or unstudied curriculum" as "those topics not included in the official curriculum" (p. 27). In both classrooms there was silence in the literal and figurative sense. The classrooms were quiet places where students were not encouraged to talk for social or even academic purposes. Parkinson also remarked on the near absence of vocabulary instruction, viewing and representing work and other forms of multimodal meaning making (Jewitt \& Kress, 2003) except in Jane's shared reading 
lessons. There was little constructivist, collaborative, or playful learning except in Jane's shared reading classes where songs and action rhymes were employed as texts for shared reading. Finally, as already noted, there were no art materials available for students to use during free time and the use of toys was limited to recess time.

Related to these silences was the observation that in one classroom, independent work primarily consisted of cognitively undemanding tasks that allowed the teacher to complete record keeping requirements. After morning message activities, students worked independently to complete a few pages of a booklet that the teacher had made for each of them. The booklet contained photocopied worksheets for reviewing colours, practicing phonics, forming letter shapes and patterning. When the children had completed that work, they were free to look at a book, do a dot-to-dot worksheet or pull out their "anything" books to draw a picture or copy down words and names from lists and posters mounted around the room.

Table 1 shows that graphophonics instruction was the main focus of shared reading and writing lessons. Emma's morning message was made up of two or three sentences with missing letters and words, incorrect uppercase or lowercase letters, missing punctuation and incorrect grammar. While the explicit teaching of graphophonics to grade one students is mandated in the Languagel-8 curriculum, other components of the official Language 1-8 curriculum such as Media Literacy were not being addressed during Holly's visits. We would argue too that the pervasive discourse of levels and levelling was mediating teachers' curriculum planning. As do DRA assessments, assigning difficulty levels to instructional and independent reading texts enables teachers and students to keep track of certain aspects of reading development while ignoring others. Children's purposes, interests, multimodal and multilingual resources are not acknowledged in the levelling process. Using levels alone conveys to teachers and students that reading development is a monolingual, linear path (Edwards, 2009). As a result, many students must come to view themselves through a lens that at best restricts their vision and at worst characterizes them as deficient in some way.

Like Sally Lubeck (2000), we are concerned that teachers' commitments to authentic literacy practices may be eroded by the relentless imposition of accountability work. The most pressing challenge for the teachers who participated in the study was lack of time, but even when time was available, that time was being used for additional assessments and record keeping. The absence of cognitively demanding and authentic literacy events was especially problematic for Emma's students since most of them were already achieving below the standard for their grade. Scott, Teale, Carrie, Johnson, and Morgan (2009) found that low performing students benefit from instruction that is "hands on, differentiated, provocative, and collaborative - and most important, fun, creative, relevant, and meaningful" (p. 339). Moreover, when they asked a group of teachers working with struggling readers and writers how they could tell if their instruction was making a difference, the teachers made no mention of standardized tests.

Let us just say as our first observation that not one of these educators mentioned standardized tests as an effective means of assessing student literacy learning. What they did say were things consistent with this quote from Mona: "The level of participation in a book discussion or a lesson is also a good indicator of 
whether or not a strategy is working." (Scott et al., 2009, p. 341)

The notion of a null curriculum is related to the notion of hidden curriculum. For example, if students' lives at school consist of short-lived, undemanding tasks, there is reason to suspect that they will graduate from school prepared for low paying service work rather than active participation in the knowledge economy. Moreover, without opportunities to engage in tasks that require sustained attention during the primary grades, they may not acquire the attention span or interests needed for the independent inquiry projects assigned in higher grades. Even students who access rich learning opportunities outside of school may come to regard school work simply as work that must be done, but not in a thoughtful way. We can only conclude that the current obsession with accountability in Ontario primary classrooms may be eroding accountability to students and accountability to the mandated curriculum itself.

\section{Conclusion}

Our paper offers a response to Griffith and André-Bechely's (2008) call for research to "attend to the social relations of ruling that are coordinated textually" (p. 46). The twofold goal for the paper was to show that teachers' accountability work in two classrooms was taking up a great deal of instructional time and to suggest that the quantity and nature of the accountability work was undermining teachers' efforts to do the work for which they were held accountable. Through a critical examination of the teachers' work, we have documented ways in which a stream of standardized reading and writing assessments dominated their work lives, but failed to provide them with data that they saw as useful for curriculum planning. We do not mean to suggest that the teachers did not see themselves as accountable to the curriculum or to their students, but rather to suggest that assessment requirements constrained their ability to honour that commitment.

What are the implications of these findings? James Popham (2009, p. 37) observes that for more than ten years, "educators have had access to solid syntheses of empirical research showing that, if properly employed, classroom formative assessment can dramatically improve students' learning." Like Teale et al. (2009), Popham is an advocate for including assessment literacy in teacher professional development. We concur with Popham that teachers need to understand the affordances of assessments for students' learning. However, we also concur with literacy researcher and adult educator, Richard Darville (2010), who writes that educators need to become critical readers of the texts and procedures that aim to promote literacy while at the same time regulating literacy practices.

How are literacy work and literacy practices hooked into governance? I've come to see the ensemble of governmental, administrative, academic and media processes that aim both to promote literacy and to regulate its development as an adult literacy regime. I've been driven to study it - as a reader of media and policy depictions of literacy that seem just bizarre, as an advocate sucked into making arguments that sell, and distressed at accountability procedures that seem almost designed to squeeze the continual invention out of good literacy work. (p. 2) 
Rather than calling for more professional development, we therefore call for researchers and administrators to consider the possible reasons why some teachers do not incorporate assessment into their thinking about curriculum when so many professional development sessions focus on assessment and evidence-based practice. A closer look at teachers' work and how it is being organized would be a good starting point.

\section{References}

Allington, R. L., \& McGill-Frantzen, A. (2009). Comprehension difficulties among struggling readers. In S. G. Isreal \& G. G. Duffy (Eds.), Handbook of research on reading comprehension (pp. 551-568). New York, NY: Routledge.

Apple, M. W. (1979). Ideology and curriculum. London, UK:Routlege and Kegan Paul.

Apple, M. W. (2004). Ideology and curriculum ( $3^{\text {rd }}$ ed.) New York, NY: RoutledgeFalmer.

Ballet, K., \& Kelchtermans, G. (2009). Struggling with workload: Primary teachers' experience of intensification. Teaching and Teacher Education, 25(8), 1150-1157.

Beaver, J.M., \& Carter, M. A. (2004). Developmental reading assessment (DRA). Parsippany, NY: Celebration Press.

Black, S. (2004). Stroking stressed out teachers. Education Digest, 69(5), 28-32.

Carlgren, I., \& Klette, K.(2008). Reconstructions of Nordic teachers: Reform policies and teachers' work during the 1990s. Scandinavian Journal of Educational Research, 52(2), 117-133.

Clandinin, D. J., Murphy, M. S., Huber, J., \& Orr, A. M. (2010). Negotiating narrative inquiries: Living in a tension-filled midst. The Journal of Educational Research, 103(2), 81-91.

Comber, B., \& Nixon, H. (2009). Teachers' work and pedagogy in an era of accountability. Discourse: Studies in the Cultural Politics of Education, 30(3), 333-345.

Darville, R. (2010). Institutional ethnography and new literacy studies. IE Newsletter, $17(20), 2-3$.

DeVault, M. L. (2008). People at work: Life, power and social inclusion in the New Economy. New York, NY: New York University Press.

Edwards, V. (2009). Learning to be literate: Multilingual perspectives. Bristol, UK: Multilingual Matters.

Garfinkel, H. (1967). Studies in ethnomethodology. Englewood Cliffs, NJ: Prentice-Hall.

Government of Canada (2008). The well-being of Canada's children. Ottawa, Ontario, Canada: Human Resources \& Social Development Canada, Public Health Agency of Canada, \& Indian \& Northern Affairs, Canada.

Griffith, A. L., \& André-Bechely, L. (2008). Institutional technologies: Coordinating families and schools, bodies and texts. In M. L. DeVault (Ed.) People at work: Life, power, and social inclusion in the New Economy (pp. 40-56). New York, NY: New York University Press.

Griffith, A. L., \& Smith, D. E. (2005). Mothering for schooling. New York, NY: Routledge. 
Hargreaves, A. (1994). Changing teachers, changing times: Teachers' work and culture in the postmodern age. Toronto, Ontario, Canada: OISE Press.

Hoffman J. V., \& Goodman, Y. M. (2009). Changing literacies for changing times. New York, NY: Routledge.

Invernizzi, M. A., Lundrum, T. J., Howell, J. L., \& Warley, H. P.(2008). Assessment driven instruction: Towards the peaceful coexistence of test developers, policymakers, and teachers in an era of accountability. In R. D. Robinson \& M. C. McKenna (Eds.), Issues and trends in literacy education (4th ed., pp. 198-209). Boston, MA: Pearson.

Jewitt, C., \& Kress, G. (2003). Multimodal literacy. London, UK: Peter Lang.

Johnson, D., \& Kress, G. (2003). Globalisation, literacy and society: Redesigning pedagogy and assessment. Assessment in Education: Principles, Policy \& Practice, 10(1), 5-15.

Lubeck, S. (2000). On reassessing the relevance of the child development knowledge base to education: A response. Paper presented at the Early Education/Child Development SIG, American Educational Research Association (AERA) 2000, New Orleans, LA.

Manicom, A. (1995). What's health got to do with it? Class, gender, and teachers' work. In M. Campbell \& A. Manicom (Eds.) Knowledge, experience, and ruling relations: Studies in the social organization of knowledge (pp. 135-148).Toronto, Ontario, Canada: University of Toronto Press.

Murphy, S. (1998). Fragile evidence: A critique of reading. Newark, NJ: Lawrence Erlbaum.

Ontario Ministry of Education (2004). A guide to effective instruction in reading: Kindergarten - grade 3. Toronto, Ontario, Canada: Author.

Ontario Ministry of Education (2005). A guide to effective instruction in writing Kindergarten - to grade 3. Toronto, Ontario, Canada: Author.

Ontario Ministry of Education (2006a). The Ontario curriculum, grades 1-8: language. Toronto, Ontario, Canada: Author.

Ontario Ministry of Education (2006b).The kindergarten program (Rev. ed.). Toronto, Ontario, Canada: Author.

Pinar, W. F., Reynolds, W. M., Slattery, P., \& Taubman, P. M. (2008). Understanding curriculum: An introduction to the study of historical and contemporary curriculum discourses. New York, NY: Peter Lang.

Popham, W. J. (2009). 6 curriculum mistakes. American School Board Journal, 196(11), 36-38.

Purcell-Gates, V., Degener, S., \& Jacobson, E. (2004). Print literacy development: Uniting cognitive and social practice theories. Cambridge, MA: Harvard University Press.

Roberston, S. L. (2000). A class act: Changing teachers' work, globalization and the state. New York, NY: Falmer.

Scott, J. L., Teale, W. H., Carrie, D. N., Johnson, N., \& Morgan, D. (2009). Effective literacy instruction for urban children: Voices from the classroom. The Reading Teacher, 63(4), 338-341.

Shacklock, G. (1998). Professionalism and intensification in teaching: A case study of 
'care' in teachers' work. Asia-Pacific Journal of Teacher Education, 26(3), 177-190.

Smith, D. E. (1987). The everyday world as problematic: A feminist sociology. Boston, MA: Northeastern University Press.

Smith, D. E. (2005). Institutional ethnography: A sociology for people. Walnut Creek, CA: Alta Mira Press.

Smith, D. (2006). Institutional ethnography as practice. Lanham, MD: Rowman \& Littlefield Publishers, Inc.

Smyth, J., Dow, A. Hattam, R., Reid, A., \& Shacklock, G. (2000). Teachers' work in a globalizing economy. London, UK: Falmer.

Stevenson, H., Carter, B., \& Passy, R. (2007). 'New professionalism', workforce remodeling and the restructuring of teachers' work. International Electronic Journal of Leadership for Learning, 11. Retrieved December 8, 2010, from http://www.ucalgary.ca/ iejll/

Stooke, R. (2010). Investigating the textually-mediated work of institutions: Dorothy E. Smith's sociology for people. In J. Buschman, L. Given, \& G. Leckie (Eds.), Exploring the social in LIS: Critical theorists from across the disciplines (pp. 283-294). Santa Barbara, CA: Libraries Unlimited.

Teale, W. H. (2008). What counts? Literacy assessment in urban schools. The Reading Teacher, 62(4), 358-361.

Teale, W. H., Hoffman, J., Paciga, K., Lisy, J. G., \& Berkel, C. (2009). Early literacy then and now. In J. V. Hoffman \& Y. M. Goodman (Eds.), Changing literacies for changing times (pp. 76 -97). New York, NY: Routledge.

Tollefson, K. (2008). Volatile knowing: Parents, teachers, and the censored story of accountability in America's public schools. Lanham, MD: Lexington Books.

United States Department of Education (n.d.). Reading First. Retrieved December 8, 2010, from http://www2.ed.gov/programs/readingfirst

Valli L., \& Buese, D. (2007). The changing roles of teachers in an era of high-stakes accountability. American Educational Research Journal, 44(3), 519-558.

Webb R., Vulliamy, G., Sarja, A., Hamelainen, S., \& Poikonen, P-L. (2009). Professional learning communities and teacher well-being? A comparative analysis of primary schools in England and Finland. Oxford Review of Education, 35(3), 405-422.

\section{Author Biographies}

Holly Carol Parkinson is a 3rd year PhD Student in Curriculum Studies and currently teaches a PJ Language Arts course. Her research interests include teachers' work, literacy assessments, early literacy, and institutional ethnography.

Roz Stooke teaches literacy and curriculum studies at the Faculty of Education, The University of Western Ontario. Her research interests include early childhood literacy, early childhood policy, and institutional ethnography. 